\title{
Kierkegaard on the reconciliation of conscience
}

\author{
Maria J. Binetti - Martina Pavlikova
}

DOI: 10.18355/XL.2019.12.03.14

\begin{abstract}
Many authors have interpreted Kierkegaard's thought as a dialectical tragedy whose inevitable outcome is the sinking of the self in the despair of an unreconcilable consciousness. It cannot be denied that there are in Kierkegaard certain intentional excesses that may seem to support this interpretation. However, there is also in his thought a totalizing intuition and a harmonic vision of human existence that unify the dialectical struggle of the self. The deepest intention of free becoming is personal identity that does not remain as a mere unattainable end but has its concrete fulfilment in the presence of the self before God and alongside others, through the unifying force of love.
\end{abstract}

Key words: reconciliation, identity, synthesis, unity, contemporaneousness, love

\section{Introduction}

Much has been said about the unreconcilable pain of Kierkegaardian conscience. Many interpreters consider the single individual subjectivity that Kierkegaard proposes almost inhuman, and the individual has been accused of an irreparable solipsism, sunk in the despair of his own emptiness (Kralik, 2013: 439-442; Kralik, 2013: 443-451; Webb 2014: xiv-xxi; Webb 2019b).

Criticism abounds: J. Wahl, for instance, speaks of an unhappy and impossible love of the Absolute (Wahl, 1949: 451-452), whereas T. Adorno refers to the selfdestructive passion of the Kierkegaardian self (Adorno, 1969: 196). M. Taylor alludes to an irreducible "self as other" (1984: $64 \mathrm{ff}$.) abandoned in the nostalgia of a reconciliation that is never present (1980: 275). On the other hand, G. Marcel believes Kierkegaard is the least humanistic of philosophers (1968: 216) and, finally, L. Chestov states that God himself would not tolerate the harshness of Kierkegaard's Christian faith (1965: 223).

We must admit that we can find in Kierkegaard more than one reason for such a critical judgment. The idea of a contradiction between God and the natural human being, the affirmation of martyrdom as the only true expression of absolute truth and the view of the world as a prison, are only some indications of an existential pessimism and depreciation of life, justified by a human ideal that would seem to take delight in misery. (compare: Kocev et al., 2017: 88 ff.)

The threat of this dialectical tragedy is doubtless among the most difficult issues in Kierkegaardian thought. Nevertheless, the affirmation of the unhappy conscience as an inevitable outcome of singular existence seems a biased and excessively simplistic solution that ignores Kierkegaard's philosophy as a whole and even denies the fundamental coherence of his principles. Such a solution seems also to forget the intentional excesses and the strategic exaggerations to which Kierkegaard resorted in order to rouse personal conscience.

Beyond dialectical contradiction and desperation, we believe there is in Kierkegaard a synthetic and totalizing intention to which he is bound and in which every possible existence is grounded. The fact that the reconciliation of the self with itself and with the Absolute remains always open, never reaching its conclusion, does not deny the self's actual and present consistence. On the contrary, the self, full of hope, projects its reality towards an ever possible future. For Kierkegaard, spirit is presence and unity. Only against this do the threat of dissolution and the promise of future continuity acquire their true sense. 
The following pages intend to justify the idea of a reconciled conscience that, far from endorsing existential pessimism, is the foundation of the most hopeful search for human existence.

\section{Personal identity as an immanent synthesis of the self}

In Kierkegaard's view a human being's deepest aspiration is to become spirit through the active consciousness of the relation existing among all the opposed elements constituting human nature. The self is a synthesis of finitude and infinitude, time and eternity, necessity and possibility, and spirit is destined to acknowledge itself as the reflexive identity of those opposing terms. The relative and the absolute, being and thought, will and duty, the inner and the external, the phenomenon and the idea, the world and the self, etc., are all elements that subjectivity must connect in a harmonious way in order to become an integrated person who is one, identical to oneself, or, in other words, an "Enkelte".

Outside this personal synthesis, Kierkegaard conceives neither time nor eternity, finitude nor infinitude, being nor thought, etc., as viable existential possibilities. Through their union, however, each of them obtains in the other a true existential consistence so that, far from being either a contradiction of elements that reject each other or an irreconcilable opposition, the person would seem to fulfil "the true 'reconciliation' that Hegel sought" (Paci, 1954: 369).

It is true that existence presupposes contradiction as the motor of spiritual becoming. However, the aim of this opposition is the promotion and achievement of personal identity. That is why, for Kierkegaard, existence requires us to link what reason discriminates and reality unites. Free action separates in order to assemble the opposite terms contained in existence. In its action, freedom does not deny any of its essential elements but rather their contrariness, thus seeking the convergence of being and thought, will and duty, finitude and infinitude. It wishes to overcome any antagonism through a differentiated synthesis, in which the forces of the self coexist and support each other.

Thus the task peculiar to freedom consists in establishing identity at the moment of resolution through the impulse of a mysterious power that harmonizes all forces. (Lenovsky, 2015: 171-173). Under the power of freedom, the multiple energies of the self are ordered and unified towards an end, as partial moments surpassed by identity. Free decision produces personal identity through the reflexive conclusion of an inner becoming, at whose end the self "collects itself as spirit having the pure forces of the spirit" (Pap. $\mathrm{X}^{1}$ A 417, $J P$ 4, 237). In decision, the spirit "assumes its whole essence at once" (Pap. $\left.\mathrm{X}^{3} \mathrm{~A} 501, J P 1,31\right)$ in order to assert itself "in an essentially pure unity with itself" (Pap. $\mathrm{X}^{1}$ A $\left.417, J P 4,237\right)$. Its accord synthetically harmonizes the relative and the absolute, time and eternity, being and thought, etc., not by adapting to an extrinsic object but by the intensive purification of spiritual potency.

The pure accord of the spirit fulfils its highest possibility as effective power or concrete action. To act with maximum possible power means to assert the identity of the self and to determine the good in itself, which is its freedom. This free action has no external obstacles that might hinder it; in this case, where there is a will there is a way. The will, being different from abstract intellect and the faculty whose object is individual things, is able to want all those finite objects discriminated and offered to the intellect. But when the spirit becomes an infinite potency, it can achieve everything just by willing the only duty to which its deepest desire tends, its own self.

Being the synthesis of the inner and the outer, of the world and the self, when the human spirit becomes reconciled to itself it thereby becomes reconciled to the whole universe and is called upon to manifest itself in external action, to express itself in time in an instantaneous leap and to transform thought into words and action. It thus establishes an accord between the two elements mentioned by the author: "a) a

XLinguae, Volume 12, Issue 3, June 2019, ISSN 1337-8384, eISSN 2453-711X 
firm conviction and certitude (...) b) an empirical development"( Pap. II A 252, JP 1, 173). Kierkegaardian freedom is not alien to the world, because its accord demands essential belonging to the external, and this means "to let God enter with us within the practical reality of the world, in which He is certainly present" (Pap. IV A 117, JP 2, 7). Any reality, even the smallest and most insignificant one, is commensurate to the absolute and cannot be cast aside from personal reality if the spirit has truly decided in favour of the concrete synthesis that configures it. The single individual is called upon to be in the world, spiritually repeating the external and releasing, in the light of the ideal, all bonds linking the subject to the finite and the temporal. By this we do not mean a release that denies the other but one that restores its difference in the identity of personal existence.

The subjective accord achieved by the free subjectivity of the single individual assembles in a spiritual simultaneity a multiplicity of temporal and contingent forces with another eternal and necessary force; a multitude of beings and thoughts with one and the same personal reality. It is true that this accord demands a hard struggle against the destructive tendencies and the negative character of the self, but such a struggle only acquires sense through the deeper intention of "being only 'One' "( Pap. $\mathrm{X}^{4}$ A 571, JP 1, 437). If in relation to the relative it is possible to surrender to the multiple, in relation to the absolute it is only possible to fulfil the unum. The Kierkegaardian unum thus wants to be the mobile image of another unity, to which it is linked in a creatural way.

When Kierkegaard presents the spirit as the synthetic identity of conscious power or of powerful consciousness, he seeks to overcome the relative opposition that abstract intellect states in a definite way and that the choices of free will confirm. In fact, while the classic conception of free will is characterized by the distinction and separation of its components - intelligence and will, the subject and the chosen object, the act of choice and its content - the Kierkegaardian singular concentrates those terms in the identity of a sole power that has overcome the abstract moments of being and concept, of willing and understanding, of idea and strength, through the concrete identity of total action.

What we have seen so far allows to justify the reconciliation of the spirit at the immanent level of its subjective reality, where the alliance between the finite and the infinite, time and eternity, the contingent and the necessary, etc., is established. However, there is a second level of reconciliation transcendent to singular conscience, namely, reconciliation to the absolute Other, expressed in the reconciliation to other human beings. We will now dwell on this.

\section{The absolute relation of the self}

The spirit is not only fulfilled as a conscious synthesis of all the elements composing human nature, but it also establishes an essential relation to God and to our neighbour. Spiritual identity is sustained beyond itself in the union to the Other as well as to others, so that according to Kierkegaard there is no individual outside this double communion.

God's consciousness is immanent to the consciousness of sin as a total denial of the self. Sin indicates the supreme contradiction of human existence, originated in the "qualitative difference between God and man" (Pap. VIII ${ }^{1}$ A 414, JP 5, 417). Its denial reduces the latter to nothingness before God, but that very nullity is precisely the possibility of a new ex nihilo creation. The acknowledgment of sin amounts to a spiritual recreation, ordained to a renewal of the divine alliance - voluntarily broken - and the resemblance that makes God "your neighbour, your nearest, the one closest to you" (Pap. III A 165, JP 5, 176). Thus, if in a certain sense sin determines an absolutely negative reality, in an opposite sense - and due to the coincidence of opposites - it signifies the utmost a human being can achieve, as it offers an opportunity for a new absolute relationship. 
God, for Kierkegaard, is the Other of sin, but He is also "the Unique, the One and the All" (SV1 8, 135, KW 15, 25), in Whom are being, life and movement and outside Whom nothing exists. From this we can infer two things. First, at the bottom of the real everything is everything and opposites coincide, because the absolute "has to bear all these relativities and relativities which actuality is" (Pap. $\mathrm{X}^{4} \mathrm{~A}$ $25, J P 3,90)$. Second, personal freedom is called upon to discover the hidden union at the instant of decision. Existence links the finite and the infinite, time and eternity, possibility and necessity, etc., because at the bottom of the real is the One that it is capable of discovering.

Because there is One and the single individual discovers its presence, the whole universe shines in the resemblance. The relation to the Absolute liberates personal identity, allowing it to subsist, in and through the Absolute, as in its One and All. Its unmediated and absolute difference supports individual subjectivity, and its presence dilates the time of human existence for a permanently renewed encounter. Thus, the radical otherness of Kierkegaard's God is equally presence and identity.

Apart from this Kierkegaard states that the single individual is that subject for whom " 'to achieve actuality' also means willing to exist for every person, as far as one reaches" (Pap. X $\mathrm{X}^{1}$ A 632, JP 4, 159, translation altered). According to this, it seems clear that the individual is not a closed monad, refractory to subjective communication, but an existence forced to irradiate ad extra and to place itself before God and before others. There is no self without an Other, and there is no self without others. That is why the Danish existentialist has deemed it necessary to be "subjective toward all others" (Pap. VIII ${ }^{1}$ A $165, J P 4,348$ ), that is, to understand them intimately in the fulfilment of love. The capacity of one's own inwardness to be prolonged in the subjective relation to every human being determines the existence of others.

The spirit is a perfect relation to fellow human beings, established in the spiritual proximity and in the maximum communication of personal existence. For each individual, the neighbour is a "matter of conscience" (SV1 9, $130 \mathrm{ff} ., K W 16,135 \mathrm{ff}$.), and one must answer for it. In the same way in which common people have friends and partners and brothers, the single individual has neighbours, and loves them infinitely more than common people love each other. This means that the single individual loves his friend and his partner, his father and his children, infinitely more than natural love might sustain.

The single individual loves itself in its neighbours and the latter in itself, according to a relation of identity that paradoxically preserves at the same time the difference. To become a Singular means then to become a neighbour to the other, fulfilling before God the essential identity among human beings.

\section{Contemporaneousness}

What we have said so far might be summarized in a category through which Kierkegaard expresses in an exemplary way the identity of the self to itself and its relation to God and the neighbor: namely, "contemporaneousness", which expresses the actual presence of the single individual, achieved by the transcendent relation to the Absolute at the instant of every moment, both past and future. In Kierkegaard's own words, "To be totally present to oneself is the highest and is the highest task for personal life" (Pap. VII ${ }^{2}$ B 235, p. 193, KW 24, 106). Subjectivity thus has the power to assert itself in a pure accord, where time and eternity, the world and the self, the single individual and the other, mutually display the plenitude of their presence.

Being contemporaneous to oneself signals the actual and active presence of subjectivity in itself, sustained in him who is pure presence. And, given that such is the supreme power of life, Kierkegaard states that whoever is "present" is "powerful", alluding to the double temporal and modal sense of the Latin term praesent (SVI 10, $78, K W 17,74$; see also $K W 24,106)$. The force of presence is the maximum potency

XLinguae, Volume 12, Issue 3, June 2019, ISSN 1337-8384, eISSN 2453-711X 
of the spirit, elevated to the superior dynamism of the real. It has managed to vanquish the unseasonable impotence of the multiple in the transparency of a total manifestation. The contemporaneous presence of the self confirms the full actuality of the spirit and ensures the single individual against the loss of a meaningless and aimless aspiration.

The Kierkegaardian subject does not subsist in the order of alienation but of a metaphysical experience that reflects the fundamental structure of human existence, both singular and universal, worldly and divine, temporal and eternal. The alliance between phenomenon and idea, finitude and infinitude, possibility and necessity, existence and essence, receives in contemporaneousness the certitude of a self, asserted in the difference from the Other and united to the identity of fellow human beings. Contemporaneousness does not only indicate the assumption of the multiple and the temporal at the instant of spiritual self-presence, but also the Presence of another that, far from erasing personal identity, sustains the single individual "unum" in its difference. It also indicates the recreation of the whole world and the incorporation of singularity to the world.

He who is contemporaneous to himself renounces the illusion of memories or tomorrow's anxiety, because he concentrates his time in a unique now, beyond temporality, whereas he who is absent becomes the most unhappy of mortal beings, because he alienates the very substance of his life. The most unhappy among them denies both his presence and his present. Whether he lives in the fantasy of the past or in that of the future, he dies to his own existence and kills in impotence both memories and authentic hope. On the contrary, an authentically free subjectivity possesses the totality of its own life, because both past and future converge in the same continuous force of concrete eternity, which, as Webb points out, is a moment of joy for Kierkegaard, a moment in which "the otherwise infinite distance between terrestrial joy and eternity's paradisiac blessedness begins to shrink" (Webb 2014, 227; see also Webb 2019a). In Kierkegaard's own words: "What is joy, or what is it to be joyful? It is truly to be present to oneself; but truly to be present to oneself is this today, this to be today, truly to be today" (SVI 11, 40, KW 18, 39).

The presence of the self to itself is achieved through the reflexive development of the spirit and consummated in decision, through which the self "experiences all its personal energy" and "feels in possession of everything that is" (SV1 2, 40, KW 4,42 ), having no alternative to its own affirmation. Thus decision is to Kierkegaard "the one by essence" ( $S V 18,180, K W 15,79)$, fulfilling any other union. Subjectivity, by choosing itself, "decides everything" ( $S V 18,180, K W 15,79$ ), and its presence thus communes with the totality of the real.

The fact that freedom fulfils contemporaneousness means that it is the reduplication of itself as subject and object, act and content, source and end of its own reflexive action. By becoming present to itself, subjectivity reduplicates its original nature in its present condition and reestablishes its identity in its multiple becoming (Mahrik, Kralik, Tavilla 2018). From this point of view, contemporaneousness indicates pure actuality, with the self as original actum and metaphysical primum. We are dealing here with pure actuality that is also activity pursued in time and open to the finite. While the action of freedom concentrates its intensity in the Archimedean point that transcends it, the constantly open rhythm of its presence opens the spirit to the other and confirms the spirit, in the world, beyond it.

The identity of the self is, in time, a continuous process of differentiation and acquisition, deprived of a conclusion, but nonetheless total and concrete in each instant of its action. Because there is no last stop, subjectivity subsists in a continuous manifestation. But this does not mean that it should consider itself the alienated unhappy consciousness of the one who wishes the impossible, for the inexhaustible "aperture of the self" (Webb 2017: 456) does not reject its instantaneous consummation. It is true that relative differences are permanently reinstated in time, but their reinstatement has 
the simple sense of unity, on which all the forces of the self are grounded and to which they are ordained.

Clearly the perennial issue of the one and the many, approached by Kierkegaard from the point of view of subjective dynamism, is here at stake. In this question we are inclined to discern in Kierkegaard's thought a philosophy of identity grounded in absolute difference. And in this sense, it is our belief that Kierkegaard has not contributed to the displacement of the metaphysics of presence by putting in its place an "inter-esse" or a "being-in-the-middle-of", revealing the deficiency of an existence submitted to permanent becoming (see, however, Ferreira 2011; Ferreira 2015). On the contrary, we believe that the deepest intention of his thought is to reconstruct a strong and different subject, but one that is united to the one force of the whole.

\section{The unity of love}

Love is the only bond capable of reinstating the face of the self that is one, inseparable from God and fellow human beings, a bond of perfection, a force of unity and total reality. Love pronounces the final word in Kierkegaard's thought, because it names the only power capable of erasing the force of contradiction and the impotence of nothingness, thus becoming the blissful reconciliation of the self. In other words, the positive solution of what is often reduced to a dialectical tragedy lies in the affirmation of love that unites while maintaining the difference.

Kierkegaard has sanctioned the excellence of love in the following claim: "What is it that endures when everything is changed? It is love. What is it that remains when the imperfect is abolished? It is love. What is it that witnesses when prophecy is silent? It is love. What is it that does not cease when the vision ends? It is love. What is it that sheds light when the dark saying ends? It is love. [...] What is it that is never changed even though everything is changed? It is love; and that alone is love, that which never become something else" (SV1 3, 273-274, KW 5, 55). The privileges of immutability, permanence and certitude are due to love's being "the source of all things and the deepest foundation of spiritual life" (SV1 9 207, KW 16, 215). And this entails a double significance. In the first place, that of being the unyielding bottom of subjectivity, to which every development must return. In the second place, that of indicating substantively the reality of God, in whom subjectivity is grounded. In love, that which is freely separated returns to the One, asserting its individuality in an undifferentiated unity: a strange paradox, from which the created being reemerges, reconciled, in the Creator.

Spiritual presence is defined by contemporaneousness, but it is fulfilled only by love, "by nature entirely present everywhere" and "by essence essentially inexhaustible in all its richness" ( $S V 19,7, K W 16,3)$. Moreover, if the task of the self is to retrieve its essential purity in a present accord, then love is the foundation, the task and the cause of singularity, because in it everything is unity and the one makes the self concrete. Thus love covers a multitude of sins and forgets the nothingness that was the self. Its permanence excludes every dialectic, and its immutability rests in unity. The moment of love thus determines a total plenitude that, within temporality, is simultaneously a continual development.

The identity of love not only reconciles the self with itself and with God, but it also recreates the reality of fellow human beings. Both self and neighbour are, for Kierkegaard, parallel sites of love, and their reconciliation is justified as the actual and active realization of the essential identity among all people. From this perspective, Kierkegaard can assert that the neighbour is the only reason of life (SV1 9, 267, $K W 16,280)$ and the only thing that makes life worth living. The single individual loves himself in his neighbour and loves the neighbour in himself through the necessity of a happy union that paradoxically maintains the difference while recreating identity.

XLinguae, Volume 12, Issue 3, June 2019, ISSN 1337-8384, eISSN 2453-711X 
Before and beyond the absolute dialectic within the self lies the perfect and undiscriminated Unity, present in the human heart as a source of life, a bond of perfection and force of union. Thus love unites and purifies what free becoming distinguishes and separates. It erases nothingness from finite existence and forgets the voluntary fall into sin. Through love, anxiety and despair overcome the impossible and every person becomes contemporaneous to the eternal. As Webb puts it, "A person might be a mere nothing for omnipotence, but is made something by virtue of love, because a human being has been given the power not only to be, but to be freely in relation" (Webb 2016, 5). Love has such power that it crosses an infinite abyss as it conceives power in what is otherwise nothing.

The novelty of Kierkegaardian existence is the reconciliation of everything in the individual through the free action of love as a perfect bond. Beyond sin and faith, separation and nothingness, is love, which guarantees resemblance and consummates the force of an action that has died to its own dialectic. Many interpretations of Kierkegaard's thought: Jamie Ferreira, Sharon Krishek, Michael Strawser, and Amy Laura Hall - so prolific on such concepts as anxiety and possibility, desperation and guilt, transcendence and subjectivity - have perhaps insufficiently insisted on the idea of love as a real necessity of freedom and a vital element of the self.

The Danish existentialist's fundamental paradox is the paradox of love: that mystery of difference in the affirmation of singular identity together with the mysterious accord between differences. Love is the organ of reconciliation and, for that reason, the organ of freedom. It sustains the continuous aspiration of existence and the ideal of law. Because of love there is a neighbour and there is a God, a spiritual form and content. (Valco, 2017: 50-51). Because the Absolute is love and has no opposites, the life of the self is in principle ensured. At the supreme apex of its rupture, Kierkegaardian subjectivity discovers, in an absolute leap, the omnipotence of the amorous gift, and from that moment the relation to God is "sheer joy" (Pap. $\mathrm{XI}^{2} \mathrm{~A} 208, J P$, 440).

Singular reality subsists in love, and if its freedom must be a continuous possibility, it will also be a continuous and repeated act of love. Starting from this idea, the dialectical tragedy of Kierkegaardian existence seems to become the rejuvenated joy of loving, because it is not the failure of freedom that moves it but the ever new success of love, inexhaustible source of bliss and hope. In fact, when Kierkegaard states that the self is sin, its counterpart reads: it is an act of love. When he holds that existence separates, its reverse assures: it has separated in order to achieve union. And when he announces desperate freedom, he wants to indicate the desperation of love. In a few words, the negative character of free action leads to the transcendence of love, stronger than faith and wiser than science.

\section{Conclusions}

This paper has tried to show the deep balance of Kierkegaardian thought and the essential optimism of its existential conception. We cannot deny Kierkegaard's many exaggerations or the profusion of his hyperbolic expressions, but neither can we neglect the fact that he makes a strategic and even paroxystic use of hyperbole as an instrument employed to arouse subjectivity. Not only does he often make use of hyperbolic expressions and feelings, but his life itself often seems a hyperbole. He himself recognized the intentional excess of his words. "They had to be [excessive]," as he explained to Emil Boesen, "otherwise they are utterly useless. I am sure that when a bomb is detonated it must be thus!" (Kierkegaard, 1881: 9). The blast has been heard, but the principles of his thought have a deeper resonance than the explosion.

Neither can we deny that, for Kierkegaard, existence bears the wound of an absolute rupture. Nevertheless, the pain of separation is the price that has to be paid for an authentic encounter, "and there everything smiles, there all is gentleness" (Pap. $\left.\mathrm{X}^{3} \mathrm{~A} 737, J P 1,434\right)$. When human strength seems to falter and nothingness darkens 
the horizon, then love begins to assert the self beyond itself. When there are no more possibilities and paradise seems lost forever, the single individual is reborn from love. Because the truth of love believes everything without ever being thwarted and expects everything without ever being confounded, our weary existence rests in unity upon it.

The conclusion of this paper is thus the essential intuition of spiritual harmony, in accordance with itself, God and others. Many interpreters have asserted that the human ideal proposed by Kierkegaard is unattainable and that the perfection he describes is radically inhuman. Others have considered that "Kierkegaard is not every day's companion, even though he might be the companion of that Sunday of life which is followed by a working day" (Lombardi, 1936:9). Beyond these interpretations, what Kierkegaard has discovered is that the whole life is that great Sunday of work. The whole life is that same individual, born and found once more in every affirmation, every difference and every surmounting.

For the common, single individual, authentic existence and utter bliss lie there, in that small amount that was generously given or in that humble word that has reached the other in sweetness. Greatness lies there, each day, in the renewed task of work and rest. Human beings wish to be eternal in the very place where they are now, not in abstraction or in fantasy. Kierkegaardian existence, deemed by many inhuman and impossible, describes that simple life of common man, who recognizes himself in act and to whom the God-relationship is "sheer joy" (Pap. XI' A 208, JP 4, 440).

This article was published with the support of the Slovak Research and Development Agency under the contract No. APVV-17-0158. The authors thank Carson Webb for his linguistic suggestions on this article under the framework of the KA 107 cooperation agreement between Piedmont College and the University of Constantine the Philosopher in Nitra.

\section{Bibliographic references}

ADORNO, T. 1969. Kierkegaard. Caracas: Monte Avila. CHESTOV, L. 1965. Kierkegaard y la filosofía existencial. Buenos Aires: Sudamericana.

FERREIRA, G. 2011. Sobre uma Existential-Videnskab: o conceito de Inter-Esse no Pós-Escrito. Pensando: Revista de Filosofia vol. 2, no. 4: 85-101.

FERREIRA, G. 2015. "The Philosophical Thesis of the Identity of Thinking and Being Is Just the Opposite of What It Seems to Be": Kierkegaard on the Relations between Being and Thought. Kierkegaard Studies Yearbook, vol. 20, no. 1: pp. 13-30. KIERKEGAARD, S. 1901-1906. Søren Kierkegaards Samlede Værker. $1^{\mathrm{a}}$ ed., A. B. Drachmann, J. L. Heiberg, H. O. Lange (eds). Vols. I-XIV. København: Gyldendal. KIERKEGAARD, S. 1968-1978. Søren Kierkegaards Papirer. 2a ed. N. Thulstrup (ed). Vols. I-XVI. København: Gyldendal.

KIERKEGAARD, S. 1881. Søren Kierkegaards Efterladte Papirer. H. Gottsched (ed.). København.

KIERKEGAARD, S. 1978-2000. Kierkegaard's Writings. H.V Hong \& E.H.Hong (trans. and eds). Vols. I-XXV. Princeton: Princeton University Press.

KIERKEGAARD, S. 1967-1978. Kierkegaard's Journals \& Papers, H. V. Hong \& E. H. Hong (trans. and eds). Vols. I-VII. Bloomington-London: Indiana University Press. KOCEV, P. - KONDRLA, P. - KRALIK, R. - ROUBALOVA, M. 2017. St. Clement of Ohrid and his activities in Macedonia. In: Konstantinove Listy, vol. 10, n. 2, pp. 88-97. ISSN

$1337-8740$.

KRALIK, R. 2013. Marie Mikulova Thulstrup (1923-2013) and her work. In: Filosoficky casopis, vol. 61, no. 3, pp. 439-442. ISSN 0015-1831. KRALIK, R. 2013. The Reception of Soren Kierkegaard in Czech Language Writings. In: Filosoficky casopis, vol. 61, no. 3, pp. 443-451. ISSN 0015-183.

LE-

XLinguae, Volume 12, Issue 3, June 2019, ISSN 1337-8384, eISSN 2453-711X 
NOVSKY, L. 2015. Identity as an instrument for interpreting the socio-cultural reality. In: European Journal of Science and Theology. vol. 11, n. 5, pp. 171-184 ISSN 1841-0464.

LOMBARDI, F., 1936. Kierkegaard. Firenze: La Nuova Italia. MAHRIK, T. - KRALIK, R. - TAVILLA, I. 2018. Ethics in the light of subjectivity Kierkegaard and Levinas, In: Astra Salvensis, vol. 6, pp. 488-500. ISSN 2393-4727. PACI, E., 1954. Angoscia e relazione in Kierkegaard, Aut-Aut, $\mathrm{n}^{\circ} 23$. TAYLOR, M., 1984. Self in/as other. Kierkegaardiana, n 13.TAYLOR, M., 1980. Journeys to selfhood: Hegel \& Kierkegaard, Berkeley, California: University of California Press.

1968. Kierkegaard vivo. Madrid: Alianz. WAHL, J. 1949. Études kierkegaardiennes. Paris: Vrin. VALCO, M. 2017. The value of Dietrich Bonhoeffer's theological-ethical reading of Soren Kierkegaard. In: European Journal of Science and Theology, vol. 13, n. 1, pp. 47-58. ISSN 1841-0464.

WEBB, C. 2014. Attunements to the Good Life: Religious Joy and the Critique of Eudaemonism in the Writings of Søren Kierkegaard. Ph.D. Dissertation, Syracuse University.

WEBB, C. 2016. Power, Joy, and Kierkegaard's Implicit Critique of Spinoza. American Academy of Religion. San Antonio. 19 November.

WEBB, C. 2017. Kierkegaard's Critique of Eudaimonism : A Reassessment. Journal of Religious Ethics, vol. 45 no. 3, pp. 437-462. ISSN : 0384-9694.

Words: 5525

Characters: 34939 (19,41 standard pages)

Prof. Dr. Maria Jose Binetti

Instituto Interdisciplinario de Estudios de Género

Facultad de Filosofía y Letras

Consejo Nacional de Investigaciones Científicas y Técnicas University of Buenos

Aires,

Puan 480, Buenos Aires,

Argentina

mjbinetti@gmail.com

PhDr. Martina Pavlikova, PhD.

Faculty of Arts, Constantine the Philosopher University in Nitra,

B. Slancikovej 1,

94901 Nitra

Slovakia

mpavlikova@ukf.sk 